\title{
Living Lab Methodology as an Assessment Tool for Mass Customization
}

\begin{abstract}
Mass customization has been regularly used as a growth strategy during the last decades. The strength of this approach stems from offering products adjusted to customers' individual needs, resulting in added value. The latter resides in the word 'custom', implying unique and utilitarian products allowing for self-expression of the consumer.

Researchers and practitioners however, predominantly focused on the company's internal processes to optimize mass customization, often resulting in market failure. As a response, a framework with five factors determining the success of mass customization was developed. Additionally Living Lab methodologies have been used to improve innovation contexts that were too closed. This paper will fill a gap in the literature by demonstrating that the integration of the five factor framework in the Living Lab methodology is well suited to determine the possible success or failure of a mass customized product in the market by means of a single case study.

Keywords: Living Labs, Open Innovation, Mass Customization, User Involvement, Digital Signage
\end{abstract}

\section{Introduction}

Companies are investing significant resources (time and money) in finding new products or services that can create value. Ortt and van der Duin [1] define innovation as making a new product or service where the 'new' can be distinguished as: new to the market, the company or technology. This clarifies that innovation is a broad concept that can be tackled by using several approaches. In this paper the focus is on a specific strategy within innovation, namely mass customization. Researchers and practitioners agree that involving users can increase the likelihood of an innovation's success in case of incremental innovation $[1,2]$. The European Living Lab movement goes even further and argues that innovation should be user-driven, conducted in real life environments and involving different stakeholders[3]. They emerged from innovation contexts that were too closed, often resulting in failed innovations attributed to the lack of end-user involvement [4]. A user can be involved in the different stages of the innovation process. The goal of this paper is to determine the potential of the Living Labapproach, that has been used in several B2C and B2B innovations,

adfa, p. 1, 2011.

(C) Springer-Verlag Berlin Heidelberg 2011 
combined with a mass customization framework as an assessment tool [5] to evaluate the products' potential success in the market and optimize accordingly.

\section{Mass Customization}

Mass production has challenged companies to find new market approaches [2]. One of these was to customize products for specific customer segments. Pine [6] defined mass customization as 'developing, producing, marketing and delivering affordable goods and services with enough variation and customization that nearly everyone finds exactly what they want'. The strategy behind it is aligning a company's products with customer needs. Customization can appear in different degrees from no customization to full customization, varying pre-defined elements, parameters, etc. to choose from. The level of customization has to be adjusted to the customers' needs. To discover those needs, user research is recommended. In the past, researchers have focussed on the factors influencing companies to move from mass production to mass customization [6] and the implementation of mass customization in their strategy [7]. However, there is still a lack of research focussing on the factors determining the success of a mass customized product in the market. Broekhuizen and Alsem (2002) [8] suggested a framework with five factors impacting the success of a mass customized product, but have not tested it yet. This paper will try to fill this gap, by testing the model, and as such the success of the product, in a Living Lab environment, by means of an in depth case study. The five determining factors are:

1. Customer factors or understanding the customer needs. Companies should analyse whether customers show a need for mass customized products, meaning whether they want to be involved and are willing to pay a premium price.

2. Product factors will influence the possibilities of mass customization. There are four product factors impacting the success, namely the purchasing frequency, the luxury level of the product, the visibility of the product and the product adaptability. Purchasing frequency gives the producers the option of learning from their customers, resulting in a learning relationship that will 
be difficult to establish for other suppliers. Luxury products are in nature more expensive and will therefore be more likely to be customized than products that fulfil basic needs [6]. Products being displayed publicly are more likely to offer variety in product presentation and customers will prefer products allowing for selfexpression. Finally product adaptability impacts the costs for the company to customize the product and as such the decision to do so.

3. The market factors exist out of two characteristics influencing the use of mass customization, namely the current level of market variety (product proliferation and competitor analysis) and the willingness and ability to adopt. When market variety is high, customers are often confronted with an abundance of choices, increasing the need for customized products. The higher the adoption level, the higher the need for mass customized products.

4. The industry factors also influence the likelihood of success, namely the growth of production technology, e-commerce and the growth of flexible production technology.

5. The organization should be capable of delivering the desired products or services quickly, inexpensively and via a convenient and enjoyable configuration process.

If these five factors are successful, a company can decide to switch to mass customization and be effective in it. This framework will be researched in a Living Lab environment in order to examine the research question, does a Living Lab allow to grasp the five factors more efficiently and evaluate the potential of mass customization?

\section{$3 \quad$ Living Lab Methodology}

Living Lab-research is a state-of-the-art methodology aiming at the involvement of end-users in the innovation process. Living Labs are experimental platforms where end-users can be studied in their everyday context [9]. Living Labs confront (potential) users with (prototypes or demonstrators of) products and/or services in the innovation process [5]. This approach has three main advantages. First it assists in developing more context-specific insights on development and acceptance processes and especially the 
interaction between both. Second these experiments inform us about possible conditions for stimulating the societal and economic embedding of technology. Third embedding it in real life situations generates images of potential societal impacts of innovation [10]. Living Labs illustrate that users not only initiate the process of innovation, but can dominate the subsequent phases of product development as well [5]. Therefore this method seems appropriate to research the success factors of a mass customized product.

Pierson \& Lievens (2005) [11] identified five stages in the process configuration of Living Lab research. The case study follows those stages to test the possible success of a (new) product going from full customization to tailored customization.

1. Contextualization is an exploratory phase. Different research methods are applied to provide the required background and insights. The contextualization allows us to define the selection criteria and profiles of end-users.

2. Selection is the identification and selection of users that will be involved in the Living Lab research. In the selection phase nonprobability sampling is used, such as maximum variation based on socio demographic variables or criterion sampling trying to understand the different factors and their configuration.

3. Concretization is the initial measurement of the selected users before the technology or service is introduced. Specific characteristics of the users are measured such as their behaviour and perception on the technology.

4. Implementation is the operationally running test phase of the Living Lab. There are two major research methods being used: direct analysis by registering user actions remotely (e.g. logging) or indirect analysis by researching the motivations via focus groups, interviews and self-reporting techniques.

5. Feedback happens at the end of the Living Lab. It exists out of an ex-post-measurement detecting evolutions in the perception and attitudes towards the introduced technology or service. Additionally technological recommendations are deduced from the implementation phase.

Each of those five stages allows the focus on different success factors and therefore a Living Lab appears the most appropriate method to test the mass customization framework and optimize 
the product of the case study, digital signage content feeds, accordingly.

\section{$4 \quad$ Methodology}

The in depth case study, involes a company that recently launched an online platform delivering digital signage content feeds. The idea came from the owners' previous experience in the creation of fully customized content. The company detected a common problem for all users, namely not knowing which content to select. Therefore they decided to offer more standardized quality content, useful in various situations such as point of sale, point of wait and point of transit and easy to integrate in the existing content playlist. The aim of the study was to test the readiness of the product for market launch in Benelux and optimize the product accordingly. In this case study we will look at the potential of using the Living Lab methodology as a research tool for identifying the potential success of a mass customized product. Case studies can help to understand complex issues or add strength to existing theories. Additionally, they are the most common used method for researching technology adoption at an organizational level [12]. Considering the mass customization model of Broekhuizen \& Alsem (2002) has not been implemented in practice yet and the Living Lab method requires a natural setting [4] a combination of both discussed frameworks seemed the most appropriate for this research. A Living Lab approach offers the possibility of iteratively optimizing a product. After each step, the company involved can improve their product, organisation, strategy, etc. based on the results of the Living Lab building block. Therefore it appears to serve as a perfect tool to prepare for launching a mass customized product in the market. The different success factors of mass customization were integrated in the building blocks of the Living Lab methodology. The table gives an overview of the different phases of the Living Lab evaluating the different success factors of mass customization. This paper will only discuss the first three phases and its results because the Living Lab case is still in progress.

The research flow is visualized in the following table: 


\begin{tabular}{|c|c|c|c|c|c|}
\hline \multirow{3}{*}{ 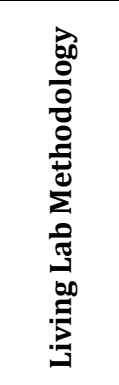 } & \multicolumn{3}{|c|}{ PRE } & INTERVENTION & POST \\
\hline & $\begin{array}{l}\text { Contextualiza } \\
\text { tion }\end{array}$ & Selection & Concretization & Implementation & Feedback \\
\hline & $\begin{array}{l}\text { Secondary } \\
\text { Research of } \\
\text { Customer } \\
\text { Product } \\
\text { Market } \\
\text { Industry } \\
\text { Organization }\end{array}$ & $\begin{array}{l}\text { Selection } \\
\text { of } \\
\text { stakehold } \\
\text { ers }\end{array}$ & $\begin{array}{l}\text { Expert } \\
\text { Interviews: } \\
\text { Evaluation of } \\
\text { first ideas }\end{array}$ & $\begin{array}{l}\text { Business } \\
\text { workshop: } \\
\text { Co-creation and } \\
\text { optimization of } \\
\text { the product }\end{array}$ & $\begin{array}{l}\text { Evaluating } \\
\text { evolutions } \\
\text { in } \\
\text { perceptions }\end{array}$ \\
\hline 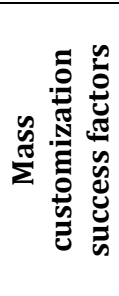 & $\begin{array}{l}\text { Research } \\
\text { focus: } \\
\text { Customer, } \\
\text { product, } \\
\text { market, } \\
\text { industry and } \\
\text { organizationa } \\
\text { l factors }\end{array}$ & $\begin{array}{l}\text { Research } \\
\text { focus: } \\
\text { Customer } \\
\text { Factors }\end{array}$ & $\begin{array}{l}\text { Research } \\
\text { focus: } \\
\text { Customer, } \\
\text { product, } \\
\text { market, and } \\
\text { industry } \\
\text { factors }\end{array}$ & $\begin{array}{l}\text { Research focus: } \\
\text { Customer, } \\
\text { Market and } \\
\text { product Factors }\end{array}$ & $\begin{array}{l}\text { Research } \\
\text { focus: } \\
\text { Customer, } \\
\text { Market and } \\
\text { product } \\
\text { factors }\end{array}$ \\
\hline
\end{tabular}

Table 1. Research Flow based on $[8,11]$

\subsection{Contextualization}

During a start-up session, a first scan of the market, the product and the organization was established. The value proposition canvas, a tool to detect the supposed added value for your (future) customers, was filled in together with the supplier of digital signage content feeds. The value proposition is created through usage of the product/service, reduction of customer risks or the efforts a customer has to make. The concept of mass customization allows a company to integrate an extra value to the customer by allowing them to personalize and configure their value package. In other words the customer is involved in the value creation process [13]. Additionally the researchers conducted desk research to generate some first impressions on the product/market fit by scanning the market, competitors and its environment.

\subsection{Selection}

In $\mathrm{B} 2 \mathrm{~B}$ research the importance of the market structure prevails [14], meaning the different stakeholders and their potential to influence the product's potential needs to be uncovered. Eight stakeholders were selected and interviewed, each varying in their 
level of involvement with digital signage content, namely operational work area, containing businesses and the wider environment [15]. This is a major difference with Living Lab research in a B2C environment were the focus is often purely on the invovement of end-users. The following table shows the stakeholder model for digital signage content:

\begin{tabular}{|c|c|c|c|}
\hline $\begin{array}{l}\text { Digital } \\
\text { Signage } \\
\text { Owner }\end{array}$ & $\begin{array}{l}\text { Software \& content } \\
\text { management } \\
\text { solutions Provider }\end{array}$ & $\begin{array}{l}\text { Integrator \& } \\
\text { hardware }\end{array}$ & Consultant \\
\hline $\mathrm{N}=2$ & $\mathrm{~N}=2$ & $\mathrm{~N}=2$ & $\mathrm{~N}=2$ \\
\hline
\end{tabular}

Table 2. Stakeholders involved in the Living Lab

\subsection{Concretization}

By organising face-to-face interviews with these different stakeholders, located in different areas of Belgium, we gained more in-depth knowledge of digital signage content, its market and customer needs.

\section{$5 \quad$ Results}

During the first three phases of the Living Lab, an evaluation of the 5 factors of the mass customization framework was established. In the contextualisation phase, the value proposition canvas and desk research showed that the digital signage industry is in a mature stage when it comes to technology. There have been some major advances in resolution and costs have been reduced significantly. As such, most businesses can now afford the hardware for digital signage. Therefore a next important issue arises: designing an appealing and conveying message that engages customers. Digital signage content providers will become more important allowing for different levels of customization and delivering a design that fits the company's image. The company being researched is capable of delivering that desired content quickly, efficiently and inexpensively by means of the content feeds. Additionally digital content is visible to a company's customers and requires the possibility to adapt it to the company's wishes. Therefore the need 
to customize digital signage content arises. In other words, the industry, product and organisation seem ready for mass customization. Nevertheless, the current Belgian market variety seems limited compared to the world and consequently the market might not be willing to accept the product yet. Additionally the customer needs are not clear for the Belgian market. Previous research has focussed on international needs and less on region specific needs. Insights into the Belgian customers will be required. The results of the contextualisation phase indicated the need to interview different stakeholders in order to gain deeper understandings of the market and customer needs.

When analysing the concretization phase, we noticed that the new product has its limitations. Although the product itself is perceived as attractive, efficient and qualitative, it does not satisfy the customers' needs completely. They show that the product will have to offer more variety and it appears too standardized on the customization ladder. More parameters will have to be added to the current offer in order to better fulfil customer needs. Additionally the product does not fit in to the Benelux market structure and value chain of digital signage. The market used to be cluttered and is slowely consolidating, resulting in an interconnected market with some bigger players. As some of the stakeholders perceive the product as an intruder in the market, it will be hard for the company to launch the product. The integration of the content feeds is not always supported by their hardware and software, meaning it needs to move away from its current coding structure. Additionally, customers buy their content together with their hardware and software offered by system integrators, which makes it difficult to operate as content provider without integrating other services. In other words the company will have to fulfil more customer and system integrator needs, change the product and their organisational strategy in order to make their product successful. The advantage of iterating during the Living Lab before continuing the following steps appears to be a useful strategy for the introduction of a mass customized product in the market. The results allowed the company to change course and optimize the product to better suit its customers' needs. In a next phase, the intervention phase, a business workshop will be 
organised with the different stakeholders involved to optimize the product even further and influence the market factors where possible. Additionally, the opportunity will arise to test whether the optimization was successful and to decide upon their market and organisational strategy from there. In a following stage, the feedback phase, a final evaluation of the product will happen.

\section{Conclusion}

The results of this study imply a working method to identify the potential success of a mass customized product. Researchers and practitioners from different industries can implement the Living Lab methodology to study the different success criteria of a mass customized product and iterate accordingly. It can be applied for incremental as well as radical innovations. The mass customization framework appears effective in analysing the potential of a mass customized product especially because it focuses on more than internal processes and additionally involves external factors such as the market and the customer. It allows managers to use it as a structure to identify and found their strategy of mass customization on. The advantage of using it in a Living Lab environment is the possibility to iterate when the product does not appear market ready and to optimize the different factors by involving a diversity of stakeholders in a real life environment. The involvement of multiple stakeholders and of the end-users allows for multiple perspectives and angles to be taken into account when evaluating the success factors. The framework contributes by structuring the Living Lab approach even further. Both strengthen each other and the results of the research.

Considering mass customization is a form of innovation, future research should focus on the applicability of the framework within a Living Lab environment for other sorts of innovations.

Although only the pre-phase of the Living Lab was performed, we believe that the next phases will only add value to the current results and allow for further product optimization. Considering this research is work in progress, we will be able to follow up on the potential of the other phases of the Living Lab and their 
applicability in determining the success of a mass customized product.

Performing user research within a B2B context is a challenge. The heterogeneity of businesses prevails and as such the selection process of users becomes more difficult. Therefore the contextualisation and selection phases of the Living Lab become more important. Defining the market structure with its different stakeholders is a first step in this process. If a mass customized product will be tested for the $\mathrm{B} 2 \mathrm{C}$ market, the focus should be more on the end users compared to multiple stakeholders. Previous Living Lab research has mainly focused on B2C Living Labs and as such the findings of this Living Lab case can serve as input on how to implement the Living Lab methodology in a B2B environment.

\section{$7 \quad$ References}

1. Ortt, J.R., Duin, P. a. Van Der: The evolution of innovation management towards contextual innovation. Eur. J. Innov. Manag. 11, 522-538 (2008).

2. Piller, F.T., Müller, M.: A new marketing approach to mass customisation. Int. J. Comput. Integr. Manuf. 17, 583-593 (2004).

3. European Commission: http://ec.europa.eu/information_society/activities/livinglabs/docs/brochure_jan09_en.pdf (2009).

4. Ståhlbröst, A.: The Living Lab Way of User Involvement, Ph.D thesis, Lulea University of Technology, Lulea (2008).

5. Schuurman, D., Marez, L. De: Structuring User Involvement in Panel-Based Living Labs. Technol. Innov. Manag. Rev. 31-38 (2012).

6. Pine, J.: Making mass customization happen: Strategies for the new competitive realities. Strateg. Leadersh. 21, 23-24 (1993).

7. Pine, J., Victor, B., Boyton, A.: Making Mass Customization Work. Harv. Bus. Rev. 71, 108-111 (1993).

8. Broekhuizen, T., Alsem, K.: Success Factors for Mass Customization: A Conceptual Model. J. Mark. Manag. 309-330 (2002). 
9. Eriksson, M., Niitamo, V., Oyj, N., Kulkki, S.: State-of-the-art in utilizing Living Labs approach to user- centric ICT innovation - a European approach. Working Paper, 1-13 (2005).

10. Frissen, V., van Lieshout, M.: To user-centred innovation processes: the role of living labs. TNO-ICT. , Delft, NL (2004).

11. Pierson, J., Lievens, B.: Configuring Living Labs for a "Thick" Understanding of Innovation. Ethnographic Praxis in Industry Conference. pp. 114-127. , Redmond, WA (2005).

12. Choudrie, J., Dwivedi, Y.K.: Investigating the Research Approaches for Examining Technology Adoption Issues. J. Res. Pract. 1, 1-12 (2005).

13. Osterwalder, A., Pigneur, Y.: Modelling Value Propositions in EBusiness. ICEC'2003 (2003).

14. De Pelsmacker, P., Van Kenhove, P.: Marktonderzoek. Garant, Antwerpen (2002).

15. Robertson, S., Robertson, J.: Mastering the Requirements Process. Addison-Wesley, Massachusetts (2013). 